\title{
Effects of replacement of black soldier fly (Hermetia illucens) larvae meal in the diets on growth performance of discus fish (Symphysodon sp.)
}

\author{
Tu P. C. Nguyen ${ }^{1 *}$, Ha N. Nguyen ${ }^{2}$, Linh T. T. Nguyen $^{1}$, \& Tri N. Nguyen ${ }^{1}$ \\ ${ }^{1}$ Faculty of Fisheries, Nong Lam University, Ho Chi Minh City, Vietnam \\ ${ }^{2}$ Research Institute for Biotechnology and Environment, Nong Lam University, Ho Chi Minh City, Vietnam
}

\begin{tabular}{|c|c|}
\hline ARTICLE INFO & ABSTRACT \\
\hline $\begin{array}{l}\text { Research Paper } \\
\text { Received: March 23, 2019 } \\
\text { Revised: September 12, } 2019 \\
\text { Accepted: September 24, } 2019 \\
\text { Keywords } \\
\text { Black soldier fly larvae } \\
\text { Discus fish } \\
\text { Formulated feed } \\
\text { Frozen beefheart } \\
\text { Growth rate } \\
\text { *Corresponding author } \\
\text { Nguyen Phuc Cam Tu } \\
\text { Email: npctu@hcmuaf.edu.vn }\end{array}$ & $\begin{array}{l}\text { This study was conducted to evaluate the replacement of fishmeal by } \\
\text { black soldier fly larvae (Hermetia illucens) (BSF) meal, frozen beefheart, } \\
\text { and commercial pellet on growth performance, survival rate, and feed } \\
\text { utilization of discus fish (Symphysodon sp.). Discus juveniles were graded } \\
\text { into small, medium and large size groups as block in a completely } \\
\text { randomized block design. Five trial diets included frozen beefheart (T1), } \\
\text { commercial feed for discus fish (T2) and three diets containing graded } \\
\text { levels of BSF as replacements for protein from fishmeal of } 0 \% \text { (T3), } 25 \% \\
\text { (T4), and } 50 \% \text { (T5). The results showed that TAN and nitrite levels } \\
\text { in the beefheart treatment were higher than those in the other ones. } \\
\text { Moreover, discus fish in treatment } 1 \text { had a higher growth rate and a lower } \\
\text { feed conversion ratio than those in the other treatments. On the other } \\
\text { hand, no statistically significant differences among the pellet treatments } \\
\text { were observed for growth rates of discus's weight, length and height } \\
\text { and feed conversion ratio }(P>0.05 \text { ). Moreover, the results showed that } \\
\text { discus fish in the two BSF treatments did not suffer from diseases and } \\
\text { had higher survival rates than those in the other treatments. }\end{array}$ \\
\hline
\end{tabular}




\title{
Ảnh hưởng của việc bổ sung nhộng ruồi lính đen (Hermetia illucens) vào thức ăn lên tăng trưởng của cá dĩa (Symphysodon sp.)
}

\author{
Nguyễn Phúc Cẩm Tú ${ }^{1 *}$, Nguyễn Ngọc Hà ${ }^{2}$, Nguyễn Thị Thùy Linh $^{1}$ \& Nguyễn Như Trí ${ }^{1}$ \\ ${ }^{1}$ Khoa Thủy Sản, Trường Đại Học Nông Lâm TP.HCM, TP. Hồ Chí Minh \\ ${ }^{2}$ Viện Nghiên Cứu Công Nghệ Sinh Học và Môi Trường, Trường Đại học Nông Lâm TP.HCM,
} TP. Hồ Chí Minh

\author{
THÔNG TIN BÀI BÁO \\ Bài báo khoa học \\ Ngày nhận: 23/03/2019 \\ Ngày chỉnh sửa: 12/09/2019 \\ Ngày chấp nhận: 24/09/2019 \\ Từ khóa \\ Cá dĩa \\ Nhộng ruồi lính đen \\ Tăng trưởng \\ Thức ăn viên \\ Tim bò tươi \\ *Tác giả liên hệ \\ Nguyễn Phúc Cẩm Tú \\ Email: npctu@hcmuaf.edu.vn
}

\section{TÓM TẮT}

Nghiên cứu này được thực hiện nhằm đánh giá khả năng thay thế protein bột cá bằng bột nhộng ruồi lính đen (Hermetia illucens) (RLD) cũng như thức ăn tim bò tươi và thức ăn viên thương mại lên tăng trưởng, tỷ lệ sống và hiệu quả sử dụng thức ăn của cá dĩa (Symphysodon sp.). Thí nghiệm được bố trí theo kiểu khối hoàn toàn ngẫu nhiên một yếu tố với cỡ cá như là khối. Yếu tố thí nghiệm là loại thức ăn gồm 5 nghiệm thức (NT): tim bò tươi xay nhuyễn (NT1), thức ăn thương mại (NT2) và 3 NT thức ăn viên có tỷ lệ thay thế protein bột cá bằng bột nhộng RLD khác nhau: $0 \%$ (NT3), $25 \%$ (NT4) và $50 \%$ (NT5). Kết quả cho thấy hàm lượng TAN và nitrite ở NT1 cao hơn các NT khác. Ngoài ra, cá dĩa ở NT1 có tốc độ tăng trưởng nhanh hơn và hệ số FCR thấp hơn và khác biệt có ý nghĩa về mặt thống kê so với các NT còn lại. Trái lại, khi so sánh giữa các $\mathrm{NT}$ thức ăn viên, tốc độ tăng trưởng về trọng lượng, chiều dài và chiều cao của cá và $\mathrm{FCR}$ không có sự khác biệt có ý nghĩa thống kê $(P>0,05)$. Kết quả thí nghiệm cũng cho thấy, ở hai NT bổ sung nhộng RLĐ cá ít bị bệnh và có tỷ lệ sống cao hơn các NT còn lại.

\section{1. Đặt Vấn Đề}

Cá dĩa (Symphysodon sp.) là một trong những loài cá cảnh đẹp. Vì vậy, cá dĩa là một trong những loài cá cảnh có giá trị thương mại cao (Chong \& ctv., 2000). Tuy nhiên, các nghiên cứu về nhu cầu dinh dưỡng và thức ăn của cá dĩa vẫn còn tương đối ít. Theo Chong \& ctv. (2000), cá dĩa có nhu cầu protein khá cao $(45 \%)$. Người nuôi cá dĩa chủ yếu dựa vào nguồn thức ăn tươi được chế biến như tim bò, sò huyết, tôm và cà rốt và các loại thức ăn tươi sống (live feed) như trùn chỉ, Artemia và ấu trùng muỗi (Chong \& ctv., 2000). Các nguồn thức ăn này dễ lây lan mầm bệnh và làm ô nhiễm môi trường nước nuôi. Thức ăn viên cho cá dĩa thường được thiết kế và đóng gói chủ yếu thích hợp cho người chơi cá cảnh, không phù hợp về mặt kinh tế cho các trang trại sản xuât cá cảnh lớn (Chong \& ctv., 2003).
Nguồn protein từ bột cá dùng để sản xuất thức ăn thủy sản đang ngày càng khan hiếm và giá thành cao. Việc tìm kiếm các nguồn nguyên liệu thay thế giàu protein làm thức ăn cho thủy sản đang được nhiều nhóm nghiên cứu quan tâm. Trong bối cảnh này, một giải pháp khả thi có thể dùng để thay thế cho bột cá trong thức ăn thủy sản là sử dụng ấu trùng của các loài côn trùng như sâu gạo Tenebrio molitor, ruồi nhà Musca domestica và đặc biệt là ruồi lính đen, là những loại nguyên liệu sẵn có, giá rẻ và có giá trị dinh dưỡng cao (Huis \& ctv., 2013). Ruồi lính đen (Hermetia illucens) (RLD) có sẵn trong môi trường tự nhiên, không lây truyền mầm bệnh như các loài ruồi khác vì RLĐ trưởng thành không có phụ bộ miệng và không ăn, không cắn phá gây hại cho người, vật nuôi. Vì vậy, RLĐ đã được sử dụng trong xử lý phân thải chăn nuôi gia súc, gia cầm (Huis \& ctv., 2013). Khi ấu trùng RLĐ chuyển 
hóa thành tiền nhộng/nhộng có hàm lượng dinh dưỡng cao: $40 \%$ protein và $30 \%$ lipid (tính trên trọng lượng khô) (Sheppard \& ctv., 1994; Newton \& ctv., 2005), thích hợp để làm thức ăn cho các loài cá nuôi như cá nheo Mỹ Ictalurus punctatus (Bondari \& Sheppard, 1981; 1987), cá hồi vân Oncorhynchus mykiss (St-Hilaire \& ctv., 2007; Sealey \& ctv., 2011), cá rô phi Oreochromis aureus (Bondari \& Sheppard, 1981; Hem \& ctv., 2008). Đối với cá cảnh, các nghiên cứu thức ăn từ côn trùng để thay thế bột cá cũng đang dần mở rộng. Nghiên cứu của Ganguly \& ctv. (2014) khi thay thế bột cá bằng bột con cào cào ở mức $25 \%$ và $50 \%$ thì không ảnh hưởng đến tăng trưởng của cá molly Poecilia sphenops.

Nghiên cứu này được thực hiện nhằm đánh giá ảnh hưởng của việc thay thế bột cá bằng bột nhộng ruồi lính đen (Hermetia illucens) lên tăng trưởng, tỷ lệ sống và hiệu quả sử dụng thức ăn của cá dĩa (Symphysodon sp.). Ngoài ra, nghiên cứu cũng nhằm so sánh hiệu quả của các loại thức ăn thay thế này với tim bò tươi và thức ăn viên thương mại.

\section{Vật Liệu và Phương Pháp Nghiên Cứu}

\subsection{Thời gian và địa điểm}

Nghiên cứu được thực hiện từ tháng 05/2018 đến tháng 09/2018 tại trại thực nghiệm Thủy sản, Khoa Thủy sản, Trường Đại học Nông Lâm TP.HCM (ĐHNL). Các chỉ tiêu chất lượng nước được phân tích tại phòng thí nghiệm của Viện Nghiên cứu Công Nghệ Sinh Học và Môi trường (RIBE) và Khoa Thủy sản, ĐHNL. Nhộng RLĐ được nuôi từ bã nành và bã dừa theo qui trình của RIBE tại khu thực nghiệm nuôi RLĐ, RIBE. Nhộng sử dụng trong nghiên cứu được thu hoạch sau 15 ngày kể từ khi trứng nở.

Cá dĩa giống được mua từ trại cá cảnh Châu Tống và chuyển về trại thực nghiệm Khoa Thủy sản, ĐHNL. Trước khi tiến hành thí nghiệm, cá được nuôi thích nghi trong bể composite (200 L) trong 4 tuần và cho ăn thức ăn dành cho cá dĩa của Công ty Fwusow Industry, Đài Loan ba lần/ngày.

\subsection{Bố trí thí nghiệm}

Thí nghiệm được bố trí theo kiểu khối hoàn toàn ngẫu nhiên một yếu tố. Yếu tố thí nghiệm là loại thức ăn gồm 5 nghiệm thức (NT): tim bò tươi xay nhuyễn (NT1), thức ăn thương mại (NT2) và ba NT thức ăn viên thay thế protein bột cá bằng bột nhộng RLĐ: $0 \%$ (NT3), 25\% (NT4) và $50 \%$ (NT5). Cỡ cá thí nghiệm được chia thành ba cỡ được bố trí như là khối: nhỏ $(4,30 \pm 0,74 \mathrm{~g} / \mathrm{con})$, trung bình $(6,06 \pm 0,80 \mathrm{~g} / \mathrm{con})$ và lớn $(8,70 \pm$ $0,77 \mathrm{~g} / \mathrm{con})$. Mỗi NT được lặp lại ba lần, mỗi lần trong một bể kính (kích thước $60 \mathrm{~cm} \times 40 \mathrm{~cm} \times$ $40 \mathrm{~cm}$, tổng cộng có 15 bể kính), mỗi bể bố trí 12 con.

Thức ăn viên thương mại cho cá dĩa dùng trong thí nghiệm là thức ăn viên công nghiệp của Công ty Fwusow Industry, Đài Loan với thành phần nguyên liệu gồm: bột mì, bột cá, bột tôm, bột dậu nành, bột sò điệp, bột mầm lúa mì, bột nhuyễn thể, bột mực, bột rong biển, bột nấm men, $\beta$ carotene, L-lysine, DL-methionine, dầu cá, vitamin premix, khoáng premix và ethoxyquin. Tim bò tươi sau khi rửa sạch được loại bỏ gân, xay nhuyễn và trữ đông với lượng đủ cho cá ăn từ đầu đến cuối thí nghiệm. Khi cho cá ăn, tim bò được rã đông và chia ra thành từng miếng nhỏ vừa miệng cá.

Thành phần dinh dưỡng của các nguyên liệu chính được sử dụng tạo thức ăn thí nghiệm như: bột cá (65\% đạm), bột nhộng RLĐ, bột khoai mì, bã đậu nành,... được cho ở Bảng 1.

Công thức thức ăn thay thế bột cá bằng bột nhộng RLĐ được phối trộn từ các nguyên liệu: bột cá, bột nhộng RLD, bột khoai mì, bã đậu nành, dầu cá biển, premix khoáng, premix vitamin, chất kết dính,...(Bảng 2). Sau khi thiết kế các công thức thức ăn thay thế, nguyên liệu được trộn đều và dùng máy xay thịt cầm tay để tạo viên thức ăn có đường kính khoảng $1,5 \mathrm{~mm}$, sâ̂y khô ở $60^{\circ} \mathrm{C}$ trong vòng 24 giờ và đóng gói bảo quản lạnh để cho cá ăn trong suốt thời gian tiến hành thí nghiệm. Khi cho ăn, dùng tay bẻ viên thức ăn vừa cỡ miệng của cá. Các công thức thức ăn thí nghiệm được trình bày trong Bảng 2 .

Sau khi chế biến, thức ăn được lấy mẫu phân tích tại phòng thí nghiệm của Công ty TNHH thức ăn gia súc Lái Thiêu để xác định thành phần dinh dưỡng của từng NT (Bảng 3 ).

\subsection{Quản lý và chăm sóc}

Trong quá trình thí nghiệm cá được cho ăn ba lần mỗi ngày bằng sàng cho ăn vào lúc 8 giờ sáng, 12 giờ trưa và 16 giờ chiều với lượng ăn thỏa mãn nhu cầu, mỗi lần cho ăn kéo dài khoảng 1 giờ. Thức ăn được rải đều vào khay nhiều lần cho đến khi cá ngừng ăn. Sau khi cho ăn cá ăn khoảng 1 
Bảng 1. Thành phần dinh dưỡng (\%) của các nguyên liệu làm thức ăn thí nghiệm

\begin{tabular}{lccccc}
\hline Nguyên liệu & Ẩm độ & Đạm & Lipid & Tro & Xơ \\
\hline Bột cá (65\%) & 6,71 & 63,81 & 7,93 & 20,5 & - \\
Bột nhộng ruồi lính đen & 14,24 & 48,56 & 24,72 & 5,62 & 9,51 \\
Bột khoai mì & 11,54 & 3,31 & 0,48 & 2,29 & 2,29 \\
Bã nành & 11,48 & 47,74 & & & 3,47 \\
Cám gạo tươi & 10,15 & 13,74 & 17,91 & 8,63 & 5,64 \\
Bột phụ phẩm gia cầm & 3,44 & 68,39 & 13,29 & 11,49 & \\
Bột huyết & 6,03 & 90,09 & & 5,48 & \\
\hline
\end{tabular}

Bảng 2. Công thức thức ăn thay thế bột cá bằng bột nhộng ruồi lính đen

\begin{tabular}{lccc}
\hline Thành phần (\%) & NT3 & NT4 & NT5 \\
\hline Bột cá & 20,00 & 15,00 & 10,00 \\
Bột nhộng ruồi lính đen & 0,00 & 6,40 & 12,80 \\
Bã nành & 22,00 & 22,00 & 22,00 \\
Bột khoai mì & 19,92 & 20,22 & 19,99 \\
Dầu cá biển & 1,00 & 1,00 & 1,00 \\
Dầu dậu nành & 2,45 & 1,20 & 0,00 \\
Cám gạo tươi & 10,00 & 10,00 & 10,00 \\
Monocalcium phosphate & 0,30 & 0,30 & 0,30 \\
Bột phụ phẩm gia cầm & 20,00 & 20,00 & 20,00 \\
Bột huyết & 2,00 & 2,00 & 2,00 \\
Premix vitamin và khoáng & 0,35 & 0,35 & 0,35 \\
Stay C 35\% & 0,03 & 0,03 & 0,03 \\
Chất kêt dính (CMC) & 1,00 & 1,00 & 1,00 \\
Methionine & 0,265 & 0,270 & 0,270 \\
Lysine & 0,080 & 0,120 & 0,145 \\
Threonine & 0,355 & 0,350 & 0,340 \\
Tryptophan & 0,090 & 0,102 & 0,112 \\
Choline chloride & 0,10 & 0,10 & 0,10 \\
Chất chống oxy hóa & 0,03 & 0,03 & 0,03 \\
Chất chống mốc & 0,03 & 0,03 & 0,03 \\
\hline Tổng & 100,00 & 100,00 & 100,00 \\
\hline
\end{tabular}

Bảng 3. Thành phần dinh dưỡng của các nghiệm thức (NT) thức ăn (\%, tính theo vật chất khô)

\begin{tabular}{lccccc}
\hline Thành phần & NT1 & NT2 & NT3 & NT4 & NT5 \\
\hline Protein & 74,66 & 44,90 & 39,76 & 38,99 & 38,87 \\
Xơ & 0,67 & 3,06 & 2,06 & 2,54 & 2,78 \\
Lipid & 13,12 & 9,08 & 7,54 & 8,70 & 7,45 \\
Tro & 6,68 & 10,89 & 9,00 & 8,84 & 8,08 \\
Độ ẩm & 74,90 & 6,25 & 9,11 & 9,14 & 9,19 \\
\hline
\end{tabular}

giờ tiến hành thu thức ăn thừa bằng sàng. Thức ăn thừa được dự trữ trong tủ đông đến khi kết thúc thí nghiệm tiến hành rã đông, sấy khô nhằm tính toán lượng thức ăn thừa cho cả thí nghiệm.
Mỗi ngày siphon và thay nước $30-50 \%$, nước sử dụng trong suốt thí nghiệm là nước máy đã qua xử lý chlorine. Hệ thống thí nghiệm có sử dụng thiết bị sục khí và cây sưởi, đảm bảo các chỉ tiêu môi trường như hàm lượng ôxy hòa tan 
và nhiệt độ đều nằm trong khoảng thích hợp cho sự tăng trưởng và phát triển của cá.

Kết thúc thí nghiệm, chúng tôi tiến hành đếm số cá ở từng NT dể tính tỷ lệ sống. Cân tất cả các cá thể ở từng NT và đo chiều dài, chiều cao của từng cá thể để tính tăng trưởng, chiều dài, chiều cao của cá và xác định hệ số chuyển đổi thức ăn. Trước khi đo chiều dài và chiều cao, cá được gây mê nhẹ bằng sản phẩm AQUI-S ${ }^{\circledR}$ (Công ty Bayer, Việt Nam) với liều lượng $10 \mathrm{~mL} / \mathrm{m}^{3}$ nước.

\subsection{Chỉ tiêu theo dõi}

\subsubsection{Các chỉ tiêu chất lượng nước}

Trong thí nghiệm, chất lượng nước được kiểm tra hàng ngày. Nhiệt độ, $\mathrm{pH}$ và oxy hòa tan đo bằng máy đo cầm tay tại từng bể thí nghiệm 2 lần/ngày vào lúc 7 giờ và 15 giờ. Hàm lượng ammonia tổng số (TAN) và nitrite $\left(\mathrm{NO}_{2-}\right)$ trong nước được lấy đi phân tích hai lần/tuần bằng phương pháp trắc quan tương ứng là indophenol và diazo hóa theo phương pháp chuẩn của $\mathrm{APHA}$ (2012) tại phòng thí nghiệm Khoa Thủy sản.

\subsubsection{Tăng trưởng và hiệu quả sử dụng thức ăn của cá dĩa thí nghiệm}

Trọng lượng cá (tất cả cá có trong bể) được cân ngay ngày đầu bố trí thí nghiệm và khi kêt thúc thí nghiệm. Chiều dài cá (chiều dài tổng cộng) được xác định theo đường thẳng từ mút đầu (miệng cá) đến cuối của vây đuôi; trong khi đó chiều cao thân cá được đo tại điểm rộng nhất của cơ thể. Đếm số cá còn lại sau thí nghiệm để tiến hành đánh giá tỷ lệ sống và sự tăng trưởng, hệ số chuyển đổi thức ăn.

Tốc độ tăng trưởng tuyệt đối về trọng lượng (weight gain $-\mathrm{WG}, \mathrm{g}$ ):

$$
\mathrm{WG}(\mathrm{g} / \text { ngày })=\left(\mathrm{W}_{\mathrm{t}}-\mathrm{W}_{0}\right) / \mathrm{t}
$$

Trong đó:

$\mathrm{W}_{0}$ : Trọng lượng trung bình cá ban đầu $(\mathrm{g})$. (g).

$\mathrm{W}_{\mathrm{t}}$ : Trọng lượng trung bình cá cuối thí nghiệm

t: thời gian thí nghiệm (70 ngày).

Tốc độ tăng trưởng chuyên biệt về trọng lượng (specific growth rate $-\mathrm{SGR}_{\mathrm{W}}, \% /$ ngày):

SGRW $(\% /$ ngày $)=\left(\ln W_{t}-\ln W_{0}\right) / t \times 100$

Tốc độ tăng trưởng chuyên biệt về chiều dài (\%/ngày):

$\operatorname{SGRL}(\% /$ ngày $)=\left(\ln \mathrm{L}_{\mathrm{t}}-\ln \mathrm{L}_{0}\right) / \mathrm{t} \times 100$
Trong đó:

$\mathrm{L}_{0}$ : Chiều dài cá đầu thí nghiệm $(\mathrm{cm})$.

$\mathrm{L}_{\mathrm{t}}$ : Chiều dài cá khi kết thúc thí nghiệm $(\mathrm{cm})$.

Tốc độ tăng trưởng chuyên biệt về chiều cao thân (\%/ngày)

SGRH $(\% /$ ngày $)=\left(\operatorname{lnH}_{\mathrm{t}}-\ln \mathrm{H}_{0}\right) / \mathrm{t} \times 100$

Trong đó:

$\mathrm{H}_{0}$ : Chiều cao cá đầu thí nghiệm $(\mathrm{cm})$.

$\mathrm{H}_{\mathrm{t}}$ : Chiều cao cá khi kết thúc thí nghiệm $(\mathrm{cm})$.

Tỷ lệ sống (survival ratio, SR):

$$
\mathrm{SR}(\%)=\mathrm{FF} \times 100 / \mathrm{IF}
$$

Trong đó:

IF: số lượng cá ban đầu (con).

FF: số lượng cá cuối thí nghiệm (con).

Hệ số chuyển đổi thức ăn (feed conversion ratio, FCR):

$$
\mathrm{FCR}=\mathrm{F}_{\mathrm{s}} /\left(\mathrm{M}_{\mathrm{f}}-\mathrm{M}_{\mathrm{i}}+\mathrm{M}_{\mathrm{c}}\right)
$$

Trong đó:

$\mathrm{F}_{\mathrm{s}}$ : Tổng khối lượng thức ăn cung cấp (g) tính theo vật chất khô

$\mathrm{M}_{\mathrm{i}}$ : Tổng khối lượng cá ban đầu $(\mathrm{g})$.

$\mathrm{M}_{\mathrm{f}}$ : Tổng khối lượng cá cuối thí nghiệm $(\mathrm{g})$.

$\mathrm{M}_{\mathrm{c}}$ : Tổng khối lượng cá chết $(\mathrm{g})$.

\subsection{Phương pháp xử lý số liệu}

Các phân tích thống kê thực hiện theo hướng dẫn của Gomez \& Gomez (1984) và Bhujel (2008). Phần trăm (\%) tỷ lệ sống được chuyển hóa bằng arcsin trước khi tiến hành phân tích thống kê, nhưng số liệu thô chưa chuyển hóa được thể hiện trong bảng. Phân tích phương sai một yếu tố (One way ANOVA) được sử dụng để so sánh sự khác biệt giữa các nghiệm thức về các số liệu tăng trưởng của cá như trọng lượng, chiều dài và chiều cao (đầu, cuối), WG, SGRW, SGRL, SGRH, tỷ lệ sống và FCR. Kiểm định Duncan được dùng để so sánh sự khác biệt giữa các mức của yếu tố thí nghiệm. Mức xác suất $P<0,05$ được chấp nhận như tiêu chuẩn đánh giá sự khác biệt có ý nghĩa thống kê. Tất cả các phân tích thống kê được thực hiện bằng phần mềm IBM SPSS Statistics for Windows, Version 19.0 (Armonk, NY: IBM Corp). 


\section{Kết Quả và Thảo Luận}

\subsection{Các thông số môi trường trong bể kính thí nghiệm}

\subsubsection{Nhiệt độ}

Trong quá trình thí nghiệm, nhiệt độ của các $\mathrm{NT}$ vào buổi sáng dao động trong khoảng $27^{0} \mathrm{C}$ $31^{0} \mathrm{C}$; trong khi đó, nhiệt độ vào buổi chiều có xu hướng tăng cao hơn trong khoảng $29,5-31,5^{0} \mathrm{C}$ (Bảng 4). Sự ổn định về nhiệt độ này là do thí nghiệm được bố trí trong khu vực được che chắn và có sử dụng dụng cụ sưởi trong bể. So với các loài cá nhiệt đới khác, cá dĩa cần nhiệt độ nước nuôi cao hơn $\left(28-30^{\circ} \mathrm{C}\right)$ (Pirhonen \& ctv., 2014; Livengood \& ctv., 2016).

\subsubsection{Giá trị pH}

Sự biến động $\mathrm{pH}$ nước bể nuôi trong thời gian thí nghiệm được thể hiện ở Bảng 4. Trong thí nghiệm, $\mathrm{pH}$ ban đầu tương đối ổn định ở khoảng $7,5-8,0$ và có sự biến động theo thời gian tiến hành thí nghiệm thấp nhất là 7,2 và cao nhất là 8,8. Càng về cuối thí nghiệm $\mathrm{pH}$ của các nghiệm thức có sự dao động quá lớn và có xu hướng tăng lên.

\subsubsection{Hàm lượng ôxy hòa tan (DO)}

Kết quả theo dõi và ghi nhận $\mathrm{DO}$ trong quá trình thí nghiệm thể hiện ở Bảng 4. Trong 10 tuần nuôi thí nghiệm, hàm lượng $\mathrm{DO}$ trong nước nuôi cá dĩa vào buổi sáng và buổi chiều dao động trong khoảng từ 5,85-6,15 mg/L. Mức dao động này nằm trong ngưỡng tối ưu cho sự sống và phát triển bình thường của cá dĩa.

\subsubsection{Ammonia}

Hàm lượng TAN trung bình trong suốt quá trình tiến hành thí nghiệm dao động từ 1,46 $3,83 \mathrm{mg} / \mathrm{L}$ (Bảng 4). Trong đó, ở NT cho ăn thức ăn tim bò tươi (NT1) có hàm lượng TAN trung bình $(3,83 \pm 3,90 \mathrm{mg} / \mathrm{L})$ cao hơn các NT khác trong suốt thời gian thí nghiệm; cho thấy thức ăn tươi sống có ảnh hưởng lớn đến chất lượng nước. Tuy nhiên, do môi trường nước được kiểm tra thường xuyên, khi thấy hàm lượng TAN tăng đột biến, chúng tôi đã tiến hành thay nước và tăng cường sục khí.

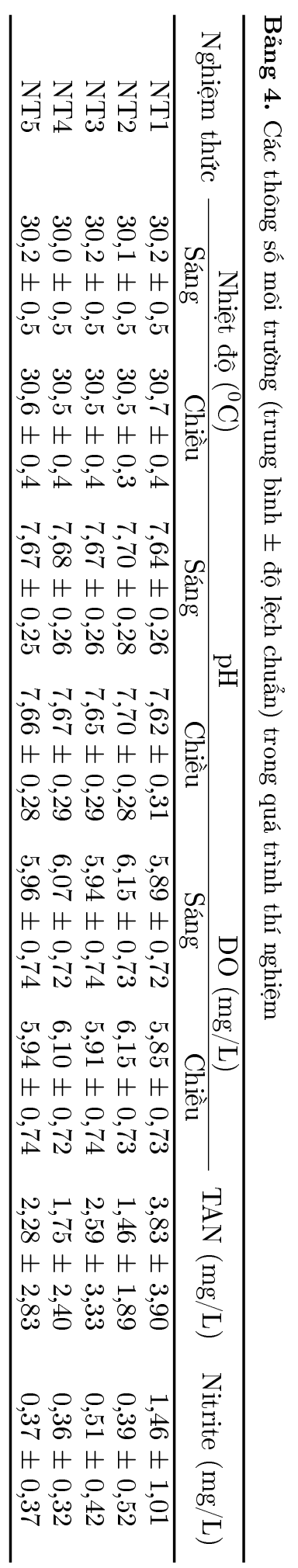




\subsubsection{Nitrite}

Hàm lượng nitrite trung bình trong suốt quá trình thí nghiệm dao động trong khoảng 0,36$1,46 \mathrm{mg} / \mathrm{L}$ (Bảng 4). Trong đó, ở NT cho ăn thức ăn tim bò (NT1) có hàm lượng nitrite $(1,46 \pm$ $1,01 \mathrm{mg} / \mathrm{L}$ ) cao hơn so với các NT còn lại trong suốt thời gian thí nghiệm. Để kiểm soát hàm lượng nitrite quá cao và giảm độc tính, chúng tôi tiến hành thay nước và bổ sung muối $\mathrm{NaCl}$ ở nồng độ $3 \mathrm{~g} / \mathrm{L}$.

\subsection{Tỷ lệ sống, tốc độ tăng trưởng và hiệu quả sử dụng thức ăn của cá dĩa}

Tỷ lệ sống và tốc độ tăng trưởng của đối tượng nuôi là những yếu tố quan trọng quyết định đến hiệu quả sản xuất. Số liệu về các chỉ tiêu tăng trưởng, tỷ lệ sống và hiệu quả sử dụng thức ăn được trình bày ở Bảng 5 .

Kết quả thí nghiệm cho thấy cá dĩa ở NT cho ăn tim bò (NT1) có tốc độ tăng trưởng cao hơn và khác biệt có ý nghĩa về mặt thống kê so với các NT cho thức ăn viên bao gồm thức ăn thương mại (NT2) và các loại thức ăn thay thế bột cá bằng nhộng RLĐ ở các tỷ lệ (NT3, NT4 và NT5) (oneway ANOVA, $P<0,05$ ) (Bảng 5). Trong khi đó, khi so sánh giữa các NT còn lại với nhau, trọng lượng trung bình cuối thí nghiệm, tốc độ tăng trưởng đối về trọng lượng, chiều dài và chiều cao của cá không có sự khác biệt có ý nghĩa thống kê $(P>0,05)$ (Bảng 5).

Trọng lượng cá trung bình cuối thí nghiệm, tăng trưởng tuyệt đối và tương đối về trọng lượng cá ở NT1 là cao nhất (lần lượt là $24,86 \pm 8,46$ $\mathrm{g} /$ con; $21,36 \pm 8,43 \mathrm{~g}$ và $2,12 \pm 0,08 \% /$ ngày), tiếp theo là các NT cho ăn thức viên thay thế (dao động lần lượt từ 15,94 $\pm 6,53 \mathrm{~g} / \mathrm{con} ; 9,58 \pm$ $6,64 \mathrm{~g}$ và $1,31 \pm 0,01 \% /$ ngày ở NT5 đến $17,67 \pm$ $8,72 /$ con; $11,29 \pm 8,722 \mathrm{~g}$ và $1,41 \pm 0,31 \% /$ ngày ở NT3) và thấp nhất là ở NT cho ăn thức ăn viên thương mại (NT2 13,92 \pm 4,20 g/con; 7,62 $\pm 3,69$ $\mathrm{g}$ và $1,15 \pm 0,06 \% /$ ngày)

Tương tự, tốc độ tăng trưởng về chiều dài (chiều dài cuối: $6,19 \pm 0,59 \mathrm{~cm}$ và SGRL: 0,36 $\pm 0,05 \% /$ ngày) và chiều cao (chiều cao cuối: 4,47 $\pm 0,69 \mathrm{~cm}$ và SGRH: $0,36 \pm 0,02 \% /$ ngày) cũng thấp nhất là ở NT cho ăn thức ăn viên thương mại, tiếp theo là các NT cho ăn thức viên thay thế và cao nhất là ở NT cho ăn tim bò tươi xay nhuyễn (chiều dài cuối: $7,43 \pm 0,85 \mathrm{~cm}$; SGRL: $0,60 \pm 0,01 \% /$ ngày; chiều cao cuối: $6,06 \pm 1,07$ cm và SGRH: $0,72 \pm 0,07 \% /$ ngày) .

Kết quả này chứng minh rằng khi cá dĩa được cho ăn tim bò sẽ có tốc độ tăng trưởng nhanh hơn so với NT cho ăn thức ăn viên. Tuy nhiên, khi so sánh giữa các NT cho ăn thức ăn viên, thức ăn có bổ sung nhộng RLĐ (NT4 và NT5) có tốc độ tăng trưởng cao hơn so với thức ăn thương mại. Điều này có thể được giải thích bởi một số lý do sau: hàm lượng protein trong tim bò tươi xay nhuyễn $(74,66 \%)$ cao hơn nhiều so với các loại thức ăn viên (dao động trong khoảng 38,87 - 44,90\%) (Bảng 3). Kết quả tương tự cũng được báo cáo bởi Wen \& ctv. (2018). Khi nghiên cứu ảnh hưởng của việc thay thế tim bò tươi bằng tim vịt và bột tôm trong khẩu phần thức ăn của cá dĩa $S$. haraldi, các tác giả này nhận thấy khi tỷ lệ tim bò trong khẩu phần giảm thì làm giảm tốc độ tăng trưởng về trọng lượng, chiều dài và chiều cao của cá dĩa. Ngoài ra, có lẽ do thức ăn tim bò tươi xay nhuyễn ở dạng mềm nên cá dễ bắt mồi hơn so với các thức ăn viên sấy khô.

Kết quả thí nghiệm cho thấy mặc dù tỷ lệ sống ở hai NT bổ sung nhộng RLĐ (NT4 và NT5) cao hơn các NT còn lại, nhưng sự khác biệt này không có ý nghĩa về mặt thống kê $(P>0,05)$ (Bảng 4$)$. Trong khi đó, khi so sánh giữa các NT còn lại với nhau, tỷ lệ sống của cá cũng không có sự khác biệt có ý nghĩa thống kê $(P>0,05)$ (Bảng 4). Trong quá trình thí nghiệm, chúng tôi nhận thấy cá ở NT cho ăn tim bò tươi có tần suất xuất hiện bệnh nhiều hơn so với các NT còn lại, đặc biệt là so với các NT thức ăn có bổ sung nhộng RLĐ. Ví dụ: ở ngày thứ 40 - 43 của thí nghiệm, tất cả ba lô (36 con) của NT ăn tim bò đều bị đen thân, trong khi đó ở NT bổ sung nhộng RLĐ cá không bị bệnh. Điều này có lẽ liên quan đến sự biến động chất lượng nước trong các bể nuôi cá cho ăn bằng tim bò tươi. Như đã đề cập ở trên, hàm lượng TAN và nitrite trong các bể cho ăn tim bò tươi xay nhuyễn thường cao hơn các NT còn lại, đặc biệt là từ ngày nuôi thứ 35 trở đi. Ngoài ra, kết quả của nhiều nghiên cứu cho thấy nhộng RLĐ nói riêng và côn trùng nói chung có chứa các nhóm chất có hoạt tính sinh học có giá trị cao. Các hợp chất này bao gồm các phân tử có dược tính khác nhau như kháng virus, kháng khuẩn và khả năng tăng cường đáp ứng miễn dịch ở người, gia súc, gia cầm và thủy sản nuôi. Bên cạnh đó, chitin và các dẫn xuất của chitin có trong vỏ côn trùng có khả năng kích thích miễn dịch (Ido \& ctv., 2015; Park \& ctv., 2015). Việc sử dụng nhộng ruồi nhà từ một loại thức ăn có hoạt tính sinh học bổ 


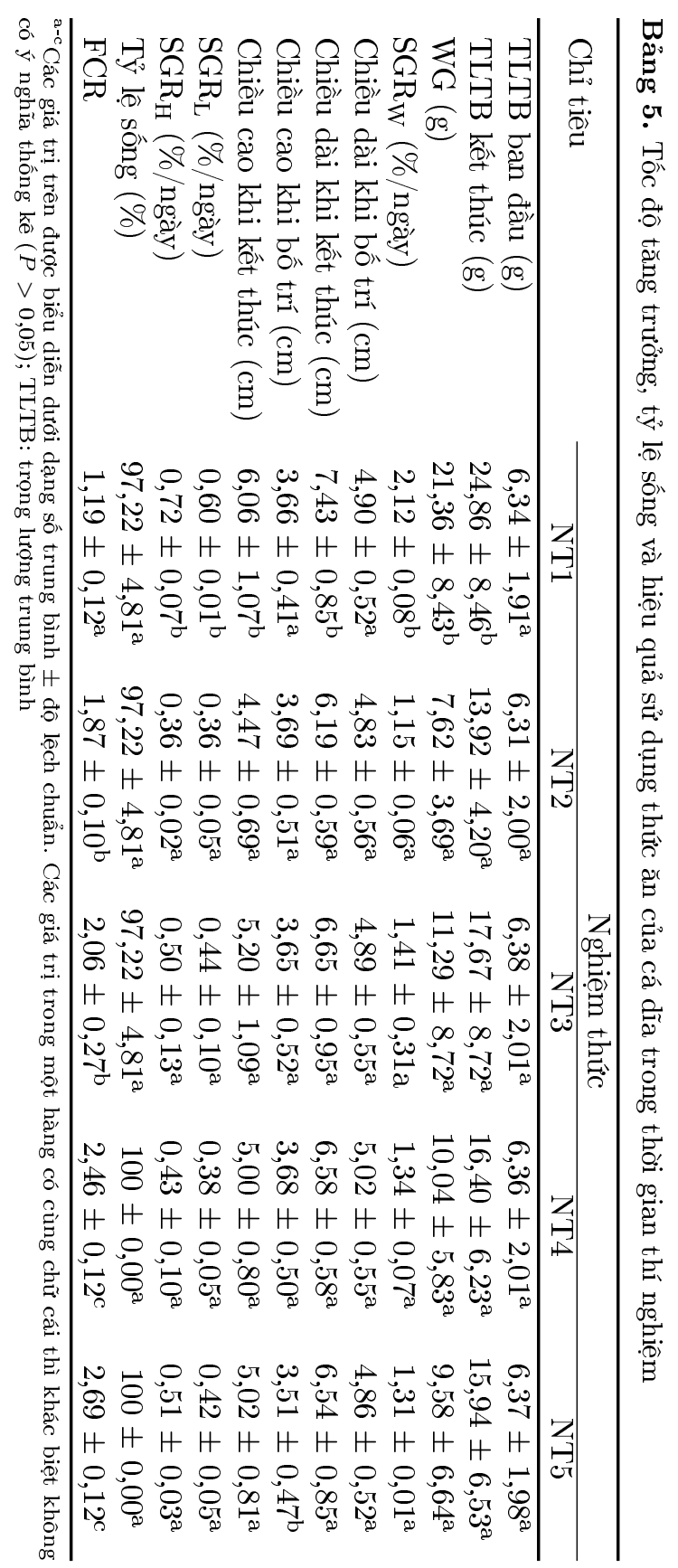


sung vào thức ăn cá tráp đỏ nhằm tăng tốc độ tăng trưởng, tỷ lệ sống và hiệu quả sử dụng thức ăn đã được các nhà khoa học ở Nhật Bản nghiên cứu thành công (Ido \& ctv., 2015).

Ngược lại, hệ số chuyển đổi thức ăn (FCR) của NT1 $(1,31)$ là thấp nhất và khác biệt rất có ý nghĩa về mặt thống kê so với các NT còn lại $(P$ $<0,001)$. Trong khi đó FCR của NT2 và NT3 thấp hơn so với NT4 và NT5. Tuy nhiên, không có sự khác biệt thống kê về $\mathrm{FCR}$ giữa các NT2 $(1,87)$ và $\mathrm{NT} 3(2,06)$ và giữa $\mathrm{NT} 4(2,46)$ và $\mathrm{NT} 5$ $(2,69)$ (Bảng 4). Như vậy, việc sử dụng thức ăn có bổ sung nhộng RLĐ có hệ số FCR cao hơn so với thức ăn thương mại. Điều này có lẽ là do hàm lượng protein trong thức ăn tim bò $(74,66 \%)$ và thương mại $(44,90 \%)$ cao hơn thức ăn viên thí nghiệm (dao dộng từ 38,87 - 39,76\%). Ngoài ra, hàm lượng xơ trong thức ăn tim bò $(0,67 \%)$ thấp hơn các NT thức ăn viên (dao động từ 2,06 $3,06 \%$ ) (Bảng 3).

Các nghiên cứu đánh giá về việc bổ sung nhộng RLĐ vào thức ăn của cá cảnh hầu như chưa có. Tuy nhiên, kết quả của nghiên cứu này đối với cá dĩa tương tự như các nghiên cứu trước đây cho các loài cá nuôi thương phẩm khác. Ở cá hồi vân O. mykiss, cá được cho ăn thức ăn chứa $15 \%$ bột nhộng RLĐ có trọng lượng trung bình cuối thí nghiệm, tăng trọng tuyệt đối và $\mathrm{FCR}$ tương tự như cá cho ăn thức ăn đối chứng chứa $36 \%$ bột cá cơm; nhưng khi cho ăn thức ăn chứa $30 \%$ bột nhộng RLĐ, các chỉ tiêu tăng trưởng của cá giảm đáng kể (St-Hilaire \& ctv., 2007). Tương tự, cá rô phi vằn Oreochromis niloticus cho ăn thức ăn có bột nhộng ruồi nhà đã giảm tăng tưởng và tăng hệ số chuyển đổi thức ăn (FCR) so với cá nuôi bằng thức ăn có chứa $52 \%$ bột cá (Slawski \& ctv., 2008). Khi thí nghiệm trên cá bơn (Psetta maxima) ở giai đoạn giống, Kroeckel và ctv (2012) cũng báo cáo rằng tăng trưởng và lượng ăn của cá giảm khi tăng tỷ lệ thay thế bột cá bằng bột nhộng RLĐ (16,5 - 75,6\%). Theo các tác giả này tăng trưởng của cá giảm có thể là do độ tiêu hóa của thức ăn giảm khi tăng tỷ lệ bột nhộng RLĐ vì độ tiêu hóa protein của bột nhộng RLĐ chỉ $63,1 \%$ so với của bột cá là $88-98 \%$. Giá trị độ tiêu hóa thấp là do hàm lượng chitin có trong vỏ nhộng mà cá không có khả năng tiêu hóa. Chitin có thể ức chế quá trình hấp thu chất dinh dưỡng từ ống tiêu hóa làm cho tăng trưởng của cá giảm (Cummins \& ctv., 2017).

Từ kết quả của nghiên cứu này cho thấy việc thay thế protein của bột cá bằng bột nhộng RLĐ trong khẩu phần ăn không ảnh hưởng đến tốc độ tăng trưởng của cá dĩa. Nhộng RLĐ có tốc độ tăng trưởng nhanh, sinh sản dễ dàng và chuyển hóa hiệu quả vật chất hữu cơ có chất lượng thấp thành nguồn protein và lipid có giá trị cao. Với giá cả tăng và thiếu hụt nguồn cung của bột cá, nhộng RLĐ có thể là một thành phần nguồn nguyên liệu thức ăn tiết kiệm và bền vững và được dùng như một nguồn protein chất lượng cao trong ngành NTTS. Việc bổ sung nguồn nguyên liệu rẻ tiền, bền vững và sẵn có ở địa phương trong thức ăn cá dĩa nói riêng và thủy sản nói chung góp phần phát triển bền vững ngành NTTS.

\section{Kết Luận}

Qua thời gian thí nghiệm cho thấy các thông số chất lượng nước cơ bản như nhiệt độ, $\mathrm{pH}$ và DO luôn được duy trì trong khoảng thích hợp cho sự tăng trưởng và phát triển bình thường của cá dĩa và không có sự khác biệt giữa các NT. Tuy nhiên, hàm lượng TAN và nitrite ở NT cho ăn tim bò tươi thường dao động trong khoảng cao hơn các NT còn lại. Kết quả thí nghiệm cho thấy cá dĩa ở NT cho ăn tim bò có tốc độ tăng trưởng nhanh hơn và hệ số FCR nhỏ hơn và khác biệt có ý nghĩa về mặt thống kê so với các NT cho thức ăn viên bao gồm thức ăn thương mại và các loại thức ăn thay thế bột cá bằng bột nhộng RLĐ với các tỷ lệ khác nhau. Trong khi đó, khi so sánh giữa các NT còn lại với nhau, tốc độ tăng trưởng về trọng lượng, chiều dài và chiều cao của cá và FCR không có sự khác biệt có ý nghĩa thống kê. Kết quả thí nghiệm cũng cho thấy, ở hai NT bổ sung bột nhộng RLĐ cá ít bị bệnh và có tỷ lệ sống cao hơn các NT còn lại. Điều này chứng tỏ việc bổ sung bột nhộng RLĐ chưa cải thiện được hiệu quả tăng trưởng và sử dụng thức ăn của cá dĩa, nhưng có khả năng làm tăng tính đáp ứng miễn dịch ở cá. Trên cơ sở này, chúng tôi đề xuất cần tiếp tục hoàn thiện thiết kế công thức thức ăn của cá dĩa và nghiên cứu đánh giá ảnh hưởng của việc bổ sung bột nhộng RLĐ lên tính kháng bệnh và đáp ứng miễn dịch ở cá dĩa và các loài thủy sản khác.

\section{Lời Cảm Ơn}

Tập thể tác giả xin chân thành cảm ơn Trường Đại học Nông Lâm TP.HCM đã tài trợ kinh phí thực hiện (Mã số: CS-SV17-TS-02). Nhộng RLĐ được nuôi từ khu thực nghiệm nuôi RLĐ được tài trợ bởi Công ty CJ, Hàn Quốc. 


\section{Tài Liệu Tham Khảo (References)}

APHA (American Public Health Association). (2012). Standard Methods for the examination of water and wastewater. $\left(22^{\text {nd }}\right.$ ed.). Washington D. C., USA: American Public Health Association.

Bhujel, R. C. (2008). Statistics for aquaculture. New Jersey, USA: Wiley-Blackwell.

Bondari, K., \& Sheppard, D. C. (1981). Soldier fly larvae as feed in commercial fish production. Aquaculture 24(0), 103-109.

Bondari, K., \& Sheppard, D. C. (1987). Soldier fly, Hermetia illucens L., larvae as feed for channel catfish, Ictalurus punctatus (Rafinesque), and blue tilapia, Oreochromis aureus (Steindachner). Aquaculture Research 18(3), 209-220.

Cummins, V. C., Rawles, S. D., Thompson, K. R., Velasquez, A., Kobayashi, Y., Hager, J., \& Webster, C. D. (2017). Evaluation of black soldier fly (Hermetia illucens) larvae meal as partial or total replacement of marine fish meal in practical diets for Pacific white shrimp (Litopenaeus vannamei). Aquaculture 473, 337-344.

Chong, A., Hashim, R., \& Ali, A. B. (2003). Assessment of soybean meal in diets for discus (Symphysodon aequifasciata HECKEL) farming through a fishmeal replacement study. Aquaculture Research 34(11), 913922 .

Chong, A. S. C., Hashim, R., \& Ali, A. B. (2000). Dietary protein requirements for discus (Symphysodon spp.). Aquaculture Nutrition 6(4), 275-278.

Ganguly, A., Chakravorty, R., Sarkar, A., Mandal, D. K., Haldar, P., Ramos-Elorduy, J., \& Moreno, J. M. P. (2014). A preliminary study on Oxya fuscovittata (Marschall) as an alternative nutrient supplement in the diets of Poecilia sphenops (Valenciennes). PLoS One 9(11), e111848.

Gomez, K. A., \& Gomez, A. A. (1984). Statistical procedures for agricultural research ( $2^{\text {nd }}$ ed.). New Jersey, USA: John Wiley \& Sons.

Hem, S., Toure, S., Sagbla, C., \& Legendre, M. (2008). Bioconversion of palm kernel meal for aquaculture: experiences from the forest region (Republic of Guinea). African Journal of Biotechnology 7(8), 1192-1198.

Huis, A. V., Itterbeeck, J. V., Klunder, H., Mertens, E., Halloran, A., Muir, G., \& Vantomme, P. (2013). Edible insects: future prospects for food and feed security. Rome, Italy: Food and Agriculture Organization.

Ido, A., Iwai, T., Ito, K., Ohta, T., Mizushige, T., Kishida, T., Miura, C., \& Miura, T. (2015). Dietary effects of housefly (Musca domestica) (Diptera: Muscidae) pupae on the growth performance and the resistance against bacterial pathogen in red sea bream (Pagrus major) (Perciformes: Sparidae). Applied Entomology and Zoology 50(2), 213-221.
Kroeckel S., Harjes A.G.E., Roth I., Katz H., Wuertz S., Susenbeth A., \& Schulz C., 2012. When a turbot catches a fly: Evaluation of a pre-pupae meal of the Black Soldier Fly (Hermetia illucens) as fish meal substitute - Growth performance and chitin degradation in juvenile turbot (Psetta maxima). Aquaculture 364(0),345-352.

Livengood, E. J., Ohs, C. L., \& Chapman, F. A. (2016). Candidate species for Florida aquaculture: Discus Symphysodon spp., a profitable but challenging species for Florida aquaculture. University of Florida IFAS Extension, Florida, USA.

Newton, G. L., Sheppard, D. C., Watson, D. W., Burtle, G. J., Dove, C. R., Tomberlin, J. K., \& Thelen, E. E. (2005). The black soldier fly, Hermetia illucens, as a manure management/resource recovery tool. Symposium on the State of the Science of Animal Manure and Waste Management. San Antonio, Texas, USA: National Center for Manure \& Animal Waste Management.

Park, S. I., Kim, J. W., \& Yoe, S. M. (2015). Purification and characterization of a novel antibacterial peptide from black soldier fly (Hermetia illucens) larvae. Developmental \& Comparative Immunology 52(1), 98106.

Pirhonen, J., Aaltonen, S., \& Järvenpää, H. (2014). Growth of domesticated discus Symphysodon sp. at constant temperatures. Aquaculture Research 45(5), 940-943.

Sealey, W. M., Gaylord, T. G., Barrows, F. T., Tomberlin, J. K., McGuire, M. A., Ross, C., \& St-Hilaire, S. (2011). Sensory analysis of Rainbow trout, Oncorhynchus mykiss, fed enriched black soldier fly prepupae, Hermetia illucens. Journal of the World Aquaculture Society 42(1), 34-45.

Sheppard, D. C., Newton, G. L., Thompson, S. A., \& Stan, S. (1994). A value added manure management system using the black soldier fly. Bioresource Technology 50(3), 275-279.

Slawski, H., Schulz, C., \& Ogunji, J. O. (2008). Evaluation of housefly maggot meal as an alternative protein source in the diet of Oreochromis niloticus. World Aquaculture 39(2), 16-18.

St-Hilaire, S., Sheppard, C., Tomberlin, J. K., Irving, S., Newton, L., McGuire, M. A., Mosley, E. E., Hardy, R. W., \& Sealey, W. (2007). Fly prepupae as a feedstuff for rainbow trout, Oncorhynchus mykiss. Journal of the World Aquaculture Society 38(1), 59-67.

Wen, B., Chen, Z., Qu, H., \& Gao, J. (2018). Growth and fatty acid composition of discus fish Symphysodon haraldi given varying feed ratios of beef heart, duck heart, and shrimp meat. Aquaculture and Fisheries $3(2), 84-89$. 